\title{
FEATURES OF THE PATERNAL FAMILY PATTERNOF ADOLESCENT GIRLS SUFFERING FROM SECONDARY OLIGOMENORRHEA
}

\author{
Grishko A.A.
}

Department of psychology, humanitarian faculty of N. Ye. Zhukovskiy National aerospace university "KhAI" Ukraine, 61070, city Kharkiv, Chkalov street, 17 E-mail: allgrishko@ukr.net, https://orcid.org/0000-0001-6641-2145

Received 11 July 2018

Formulation of the problem. Numerous research indicates high prevalence of menstrual disorders among adolescent girls. However, issues related to the pathogenesis, diagnosis and treatment of these diseases remain unresolved. Problem analysis. In psychological scientific literature it is noted that to date, more and more attention is paid to the medical and social factors of the formation of violations of menstrual function of girls. And the significance of the role of psychogenic factors is insufficient and requires further development. Meanwhile, in the process of puberty, the selective sensitivity of the reproductive system to psychological factors increases. There are indications about the significant impact of child-parent relationships on reproductive health of adolescents.

The purpose of the study is to analyze the peculiarities of the structure of the parent's family of teenage girls suffering from secondary oligomenorrhea and its possible internal impact on the development and course of the disease.

Methods of research - the method of "Drawing of the family" by L. Corman, in the processing of data, the criterion of the angle transformation of Fisher was used. Sample Description: A total of 88 teenage girls suffering from PMS and 100 healthy girls, a control group (further CG), participated in the study.

Research results. Specific structural changes in the family system, its imbalance, non-differentiation of the personal boundaries of each member of the family, the presence of signs of interpersonal dependence, dysfunctional coalitions with one of the parents were revealed. It was suggested that girls suffering from secondary oligomenorrhea, pathogenetic, predisposing role of the factor of the family in the emergence of both sexually transmitted diseases, psychosexual development in general, and menstrual function in particular.

Conclusion. The results of the study indicate that the quality of relations with parents becomes a serious prognostic sign of psychosomatic functioning and development of the personality of the adolescent.

KEY WORDS: adolescent age, violation of menstrual function, secondary oligomenorrhea, family space, pathogenic factors

\section{ОСОБЛИВОСТІ СТРУКТУРИ БАТЬКІВСЬКОЇ СІМ'Ї ДІВЧАТ-ПІДЛІТКІВ, ЯКІ СТРАЖДАЮТЬ ВТОРИННОЮ ОЛІГОМЕНОРЕЄЮ}

Гришко А.А.

Кафедра психології, гуманітарний факультет Наџіонального аерокосмічного університету «ХАІ» імені М.Є. Жуковського Постановка проблеми. Багаточисельні дослідницькі роботи вказують на високу поширеність серед дівчат-підлітків порушень менструальної функції. Однак питання, що стосуються патогенезу, діагностики та лікування даних захворювань залишаються невирішеними.

Аналіз проблеми. В психологічній науковій літературі помічено, що на сьогоднішній день все більше уваги приділяється медико-соціальним факторам формування порушень менструальної функції у дівчат. А значущість ролі психогених факторів представлена недостатньо і вимагає подальших розробок. Між тим, в процесі статевого дозрівання наростає виборча чутливість репродуктивної системи до психологічних факторів. Існують вказівки щодо значного впливу дитячобатьківських відносин на репродуктивне здоров'я підлітків.

Мета дослідження - проаналізувати особливості структури батьківської сім'ї дівчат-підлітків, які страждають вторинною олігоменореєю (далі ВОМ), і їі можливий внутрішній вплив на розвиток та перебіг захворювання.

Методи дослідження - методика «Малюнок сім'ї» по Л. Корману, при обробці даних застосовувався критерій кутового перетворення Фішера.

Опис вибірки: у дослідженні взяли участь 88 дівчат-підлітків, які страждають ВОМ, і 100 здорових дівчат - контрольна група (далі КГ).

Результати дослідження. Було виявлено специфічні структурні зміни у сімейній системі, їі незбалансованість, недиференційованість особистісних кордонів кожного члена родини, наявність ознак міжособистісної залежності, дисфункціональних коаліцій з одним із батьків. Було висунуто припущення про наявність у дівчат, які страждають вторинною олігоменореєю, патогенетичної, предиспонуючої ролі фактора сім'ї у виникненні як порушень статеворольового, психосексуального розвитку в цілому, так і менструальної функції зокрема.

(C) Гришко А. А., 2018 
Висновки. Результати дослідження вказують на те, що якість відносин з батьками стає серйозною прогностичною ознакою психосоматичного функціонування і розвитку особистості підлітка.

КЛЮЧОВІ СЛОВА: підлітковий вік, порушення менструальної функції, вторинна олігоменорея, сімейний простір, патогенні чинники.

Постановка проблеми. В останні десятиліття різко зросла значимість проблеми охорони репродуктивного здоров'я дітей та підлітків, профілактики та лікування гінекологічних захворювань в дитячому віці [9]. Однією з досить поширених форм гінекологічної патології у дівчаток-підлітків $є$ вторинна олигоменорея (далі ВОМ) - 27\% серед всіх гінекологічних захворювань $[4,6]$. Причому число випадків подібної патології неухильно зростає, що негативно позначається на загальному репродуктивному здоров'ї дівчат-підлітків $[4,7,9]$.

Етіологічні чинники, що сприяють виникненню ВОМ, надзвичайно різноманітні. У літературі можна зустріти вказівки на те, що несприятливий перебіг антенатального періоду розвитку може привести до схильності організму дівчат як до деяких ендокринопатій, так і до розвитку ряду гінекологічних захворювань, зокрема ВОМ [2]. На думку гінекологів, причинами виникнення ВОМ можуть також ставати серйозні зміни в житті дівчат - гострий стрес, зміна місця або способу життя; а можуть бути і запальні процеси в органах малого таза внаслідок хронічних інфекцій [4, с. 67 - 68]. Слід зазначити, що багато авторів повідомляють про значну роль психогених факторів у генезі ВОМ $[2,3,6]$. Але якщо в даний час медико-соціальним аспектам надання гінекологічної допомоги підліткам приділяється певна увага, то досліджень, присвячених медико-психологічним аспектам цієї проблеми, вкрай мало.

Аналіз проблеми. Підлітковий вік $є$ найбільш дисгармонійним і суперечливим у порівнянні з іншими віковими періодами розвитку особистості. Гетерохронность розвитку на внутрішньому та міжособистісному рівнях $€$ найважливішою рисою цього віку і обумовлює основні протиріччя підліткової психології [6]. Особливості перебігу такого відповідального періоду життя підлітка відкладають відбиток на все подальших періоди життя, визначаючи роботу і однієїіз кординальних біологічних функцій - репродуктивної.

Відомо, що найбільш чутливою до хронічного психоемоційного стресу $є$ репродуктивна система жіночого організму, особливо в підлітковому віці $[4,6]$. Роботи ряду дослідників показують, що в процесі статевого дозрівання наростає виборча чутливість репродуктивної системи до психологічних факторів. Одним 3 таких $є$ фактор родини - відсутність гармонії в сімейних відносинах, невірні стилі виховання, сімейні конфлікти, смерть одного з батьків і т.д. $[1,2,4,5]$. Можливий вплив структури, особливостей життєдіяльності батьківської сім'ї на формування i супровід розладів репродуктивної функції, зокрема ВОМ, на сьогоднішній день не вивчено. Тим часом доведено, що серед етіологічних чинників різних дитячих захворювань порушення системи відносин в родині займає центральне місце $[1,2,4,5]$, і якість відносин батьки/діти є головною прогностичною ознакою психосоматичного функціонування і розвитку особистості дитини $[2,5]$.

3 урахуванням сказаного виникає необхідність вивчення фактора сім'ї як можливо предиспонуючого до виникнення ВОМ.

Мета дослідження. Проаналізувати особливості структури батьківської сім'ї дівчат-підлітків, які страждають ВОМ (в порівнянні із здоровою групою дівчат), і їі можливий внутрішній вплив на розвиток та перебіг захворювання.

Методи дослідження. Методика «Малюнок сім'ї» по Л. Корману, призначена для виявлення особливостей сімейних відносин. При обробці даних застосовувався критерій кутового перетворення Фішера.

Опис вибірки. Дослідження проводилося на базі гінекологічного відділення Українського Науководослідного інституту охорони здоров'я дітей і підлітків, а також загальноосвітніх шкіл м. Харкова. У дослідженні взяли участь дівчата, які страждають ВОМ, і контрольна група здорових дівчат (далі 
КГ). Дівчата-підлітки були розділені на дві вікові групи: 13-14,5 і 15-17 років. Загальна кількість дівчат-підлітків склало 188 осіб.

Результати дослідження. Для порівняння графічних зображень і можливості інтерпретації малюнків в групах хворих і здорових дівчат-підлітків, скористаємося таблицею 1.

Таблица 1.

Значні відмінності в зображеннях «Малюнок сім'ї» здорових дівчат та страждаючих ВОМ

\begin{tabular}{|c|c|c|c|c|c|c|}
\hline \multirow{2}{*}{$\begin{array}{c}\text { Діагностичні ознаки } \\
\text { малюнку сім'ї }\end{array}$} & \multicolumn{4}{|c|}{ Частота проявів, \% } & \multicolumn{2}{|c|}{$\begin{array}{l}\text { Достовірність } \\
\text { відмінностей, } \varphi\end{array}$} \\
\hline & $\begin{array}{l}1 \text { гр. } \\
\text { BOM, } \\
(\mathrm{n}=40)\end{array}$ & $\begin{array}{l}2 \text { гр. } \\
\text { BOM, } \\
(\mathrm{n}=48)\end{array}$ & $\begin{array}{c}1 г \mathrm{p} . \\
\mathrm{K} \Gamma \\
(\mathrm{n}=50)\end{array}$ & $\begin{array}{c}2 \text { гр. } \\
\text { КГ } \\
(\mathrm{n}=50)\end{array}$ & $\begin{array}{l}\Gamma \mathrm{p} . \\
1-1\end{array}$ & $\begin{array}{l}\Gamma \mathrm{p} . \\
2-2\end{array}$ \\
\hline $\begin{array}{l}\text { Розташування малюнку на аркуши: } \\
\text { - на весь лист }\end{array}$ & 50 & $-/-$ & 14 & 9,1 & 1,37 & 1,38 \\
\hline - у нижній частині листа & 25 & 14,3 & 14 & $-/-$ & 0,48 & $1,78^{*}$ \\
\hline - на верхній частині листа & $-/-$ & 14,3 & 14 & 9,1 & 1,20 & 0,41 \\
\hline - 3 правого боку & 25 & $-/-$ & 14 & 18,2 & 0,48 & $2,05 *$ \\
\hline - с лівого боку & $-/-$ & $-/-$ & $-/-$ & $-/-$ & $-/-$ & $-/-$ \\
\hline - равномірний розподіл & $-/-$ & $-/-$ & 44 & 54,5 & $2,36^{* *}$ & $3,10 * *$ \\
\hline $\begin{array}{l}\text { - займає малу центральну частину } \\
\text { листа }\end{array}$ & $-/-$ & 71,4 & $-/-$ & 9,1 & $-/-$ & $3,50 * *$ \\
\hline $\begin{array}{l}\text { Місце розташування членів сім'ї: } \\
\text { - тісне відносно один до одного }\end{array}$ & 25 & 57,1 & $-/-$ & 18,2 & $1,67^{*}$ & $2,08 * *$ \\
\hline $\begin{array}{l}\text { - невелика дистанція між членами } \\
\text { родини }\end{array}$ & 25 & 28,6 & 79 & 81,8 & $1,94^{*}$ & $2,83 * *$ \\
\hline -розосереджені в різних місцях & 50 & 14,3 & 21 & $-/-$ & 1,05 & $1,78^{*}$ \\
\hline $\begin{array}{l}\text { - найбільш близьке розташування } \\
\text { дитячої фігури до матері }\end{array}$ & 75 & 35,7 & 7 & 9,1 & $2,65 * *$ & $1,67 *$ \\
\hline $\begin{array}{l}\text { - найбільш близьке розташування } \\
\text { дитячої фігури до батька }\end{array}$ & $-/-$ & 14,3 & $-/-$ & 18,2 & $-/-$ & 0,26 \\
\hline $\begin{array}{l}\text { - найбільш близьке розташування } \\
\text { дитячої фігури досиблінгу }\end{array}$ & $-/-$ & $-/-$ & 26 & 18,2 & $1,71^{*}$ & $2,05^{*}$ \\
\hline - дитяча фігура ізольована від інших & 25 & 14,3 & $-/-$ & 9,1 & $1,67^{*}$ & 0,41 \\
\hline $\begin{array}{l}\text { Руки на малюнку прибрані за спину: } \\
\text { - у всіх }\end{array}$ & $-/-$ & $-/-$ & 7 & 27,3 & 0,80 & $2,44 * *$ \\
\hline - крім дитячої фігури & $-/-$ & $-/-$ & $-/-$ & $-/-$ & $-/-$ & $-/-$ \\
\hline - крім сиблінга & $-/-$ & $-/-$ & $-/-$ & $-/-$ & $-/-$ & $-/-$ \\
\hline - крім батька & $-/-$ & 7,1 & 7 & $-/-$ & 0,80 & 1,19 \\
\hline - крім матері & $-/-$ & $-/-$ & $-/-$ & $-/-$ & $-/-$ & $-/-$ \\
\hline $\begin{array}{l}\text { Невідповідність реальному складу } \\
\text { сім'ї. Не малюють: } \\
\text { - батька }\end{array}$ & $-/-$ & $-/-$ & 35 & 9,1 & $2,05^{*}$ & 1,38 \\
\hline - мати & $-/-$ & $-/-$ & 21 & $-/-$ & 1,51 & $-/-$ \\
\hline - сиблінга & $-/-$ & 14,3 & 14 & $-/-$ & 1,20 & $1,78^{*}$ \\
\hline - дитячу фігуру & 25 & 21,4 & 14 & 27,3 & 0,48 & 0,35 \\
\hline
\end{tabular}




\begin{tabular}{|c|c|c|c|c|c|c|}
\hline \multirow{2}{*}{$\begin{array}{c}\text { Діагностичні ознаки } \\
\text { малюнку сім'ї }\end{array}$} & \multicolumn{4}{|c|}{ Частота проявів, \% } & \multicolumn{2}{|c|}{$\begin{array}{l}\text { Достовірність } \\
\text { відмінностей, } \varphi\end{array}$} \\
\hline & $\begin{array}{c}1 \text { гр. } \\
\text { ВOM, } \\
(\mathrm{n}=40)\end{array}$ & $\begin{array}{r}2 \text { гр. } \\
\text { ВOM, } \\
(\mathrm{n}=48)\end{array}$ & $\begin{array}{c}1 \text { гр. } \\
\text { КГ, } \\
(\mathrm{n}=50)\end{array}$ & $\begin{array}{c}2 \text { гр. } \\
\text { КГ, } \\
(\mathrm{n}=50)\end{array}$ & $\begin{array}{l}\Gamma \mathrm{p} . \\
1-1\end{array}$ & $\begin{array}{l}\Gamma \mathrm{p} . \\
2-2\end{array}$ \\
\hline $\begin{array}{l}\text { Невідповідність реальному складу } \\
\text { сім'ї. Доданий: } \\
\text { - батько }\end{array}$ & $-/-$ & 14,3 & $-/-$ & $-/-$ & $-/-$ & $1,78^{*}$ \\
\hline - мати & $-/-$ & $-/-$ & $-/-$ & $-/-$ & $-/-$ & $-/-$ \\
\hline - сиблінг & $-/-$ & $-/-$ & $-/-$ & $-/-$ & $-/-$ & $-/-$ \\
\hline $\begin{array}{l}\text { Малювання додаткових фігур: } \\
\text { - бабусі, дідусі }\end{array}$ & 25 & 7,1 & 21 & 9,1 & 0,16 & 0,19 \\
\hline - двоюрідні брати, сестри & $-/-$ & $-/-$ & $-/-$ & 9,1 & $-/-$ & 1,38 \\
\hline - домашні тварини & $-/-$ & $-/-$ & 28 & 36,4 & $1,79 *$ & $3,08 * *$ \\
\hline $\begin{array}{l}\text { Послідовність малювання: } \\
\text { - перша дитяча фігура }\end{array}$ & 25 & 14,3 & $-/-$ & 9,1 & $1,67 *$ & 0,41 \\
\hline - першафігура батька & 50 & 35,7 & 43 & 36,4 & 0,24 & 0,04 \\
\hline - перша фігураматері & 25 & 50 & 43 & 54,5 & 0,65 & 0,23 \\
\hline - перша фігурасиблінга & $-/-$ & $-/-$ & 14 & $-/-$ & 1,20 & $-/-$ \\
\hline - остання фігура батька & 25 & 21,4 & 14 & 18,2 & 0,48 & 0,20 \\
\hline - остання фігура матері & 50 & 14,3 & $-/-$ & 18,2 & $2,56 * *$ & 0,26 \\
\hline - остання фігура сиблінга & 25 & 21,4 & 72 & 45,4 & $1,66^{*}$ & 1,30 \\
\hline - останнядитяча фігура & $-/-$ & 42,9 & 14 & 18,2 & 1,20 & 1,37 \\
\hline $\begin{array}{l}\text { Величина фігур: } \\
\text { - найбільша фігура батька }\end{array}$ & $-/-$ & 50 & 36 & 63,6 & $2,08 * *$ & 0,69 \\
\hline - найбільша фігура матері & 100 & 35,8 & 43 & 18,2 & $2,91 * *$ & 1,01 \\
\hline - найбільша фігура сиблінга & $-/-$ & 7,1 & 7 & 18,2 & 0,80 & 0,86 \\
\hline - найбільша дитяча фігура & $-/-$ & 7,1 & 14 & $-/-$ & 1,20 & 1,19 \\
\hline - найменша фігура батька & $-/-$ & $-/-$ & 21 & 9,1 & 1,51 & 1,38 \\
\hline - найменша фігураматері & $-/-$ & 14,3 & $-/-$ & 18,2 & $-/-$ & 0,26 \\
\hline - найменша фігурасиблінга & 50 & 35,7 & $-/-$ & 18,2 & $2,56^{* *}$ & 1,00 \\
\hline - найменша дитяча фігура & 50 & 50 & 36 & 18,2 & 1,48 & $1,73 *$ \\
\hline $\begin{array}{l}\text { - } \quad \text { найменша } \text { фігурадомашньої } \\
\text { тварини }\end{array}$ & $-/-$ & $-/-$ & 43 & 36,3 & $2,32 * *$ & $3,08 * *$ \\
\hline $\begin{array}{l}\text { Відповідність статі дитячої фігури } \\
\text { реальній статі: } \\
\text { - відповідає }\end{array}$ & 75 & 50 & 100 & 100 & $1,78^{*}$ & $3,93 * *$ \\
\hline - не відповідає & 25 & 50 & $-/-$ & $-/-$ & $1,67^{*}$ & $3,77 * *$ \\
\hline $\begin{array}{l}\text { Виконання малюнка: } \\
\text { - «примітивний» малюнок }\end{array}$ & 25 & 50 & 3 & $-/-$ & 1,19 & $3,77 * *$ \\
\hline - «якісний» малюнок & 75 & 50 & 86 & 100 & 0,48 & $3,93 * *$ \\
\hline - намальовані тільки голови & $-/-$ & $-/-$ & 11 & $-/-$ & 1,04 & $-/-$ \\
\hline $\begin{array}{l}\text { Труднощі зображення одного } 3 \\
\text { членів сім'ї: } \\
\text { - батька }\end{array}$ & $-/-$ & 7,1 & $-/-$ & $-/-$ & $-/-$ & 1,19 \\
\hline
\end{tabular}




\begin{tabular}{|l|c|c|c|c|c|c|}
\hline \multirow{2}{*}{$\begin{array}{c}\text { Діагностичні ознаки } \\
\text { малюнку сім'ї }\end{array}$} & \multicolumn{4}{|c|}{ Частота проявів, \% } & \multicolumn{2}{c|}{$\begin{array}{c}\text { Достовірність } \\
\text { відмінностей, } \varphi\end{array}$} \\
\cline { 2 - 8 } & $\begin{array}{c}1 \text { гр. } \\
\text { ВОМ, } \\
(\mathrm{n}=40)\end{array}$ & $\begin{array}{c}2 \text { гр. } \\
\text { ВОМ, } \\
(\mathrm{n}=48)\end{array}$ & $\begin{array}{c}1 \text { гр. } \\
\text { КГ, } \\
(\mathrm{n}=50)\end{array}$ & $\begin{array}{c}2 \text { гр. } \\
\text { КГ, } \\
(\mathrm{n}=50)\end{array}$ & $\begin{array}{c}\text { Гр. } \\
1-1\end{array}$ & $\begin{array}{c}\text { Гр. } \\
2-2\end{array}$ \\
\hline - матері & 50 & 28,6 & $-/-$ & $-/-$ & $2,56 * *$ & $2,67 * *$ \\
\hline - дитячої фігури & $-/-$ & 7,1 & 7 & $-/-$ & 0,80 & 1,19 \\
\hline $\begin{array}{l}\text { На малюнку члени родини зайняті } \\
\text { однією діяльністю }\end{array}$ & 25 & 50 & 7 & 45,4 & 0,87 & 0,23 \\
\hline $\begin{array}{l}\text { На малюнку кожен член родини } \\
\text { зайнятий своєю справою }\end{array}$ & 25 & 7,1 & 14 & 18,2 & 0,48 & 0,86 \\
\hline Не змогли намалювати свою сім'ю & $-/-$ & $-/-$ & 14 & 9,1 & 1,20 & 1,38 \\
\hline
\end{tabular}

Примітка:

- $\varphi$ - критерій кутового перетворення Фішера;

$-*-\mathrm{p} \leq 0,05, * *-\mathrm{p} \leq 0,01$

- / - - діагностична ознака малюнка відсутня.

Для малюнків дівчат, які страждають ВОМ, характерно розташування на весь лист (в 50\% випадках в молодшій групі); тісне розташування членів сім'ї відносно один одного (в 57,1\% випадків в старшій віковій групі і в $25 \%$ випадках в молодшій). Як правило, це властиво сім'ям, де порушені особисті межі їі представників. Ще $25 \%$ дівчат молодшої вікової групи малюють дитячу фігуру ізольовано від інших членів сім'ї. А Я. Варга [1, с. 10 - 11] вважала, що це може свідчити про відсутність задоволення «психічних потреб» дитини в сім'ї. Крім того, «... найменша людина в цій позиції може «обслуговувати»потреби дорослого, наприклад, улюбленої мами або тата, не маючи можливості повноцінно пройти свої стадії психічного розвитку» [1, с. 11]. Подібні діагностичні параметри малюнка сім'ї були відзначені в дослідницькій роботі Фролової Є.В. [8, с. 156 - 157] - вони були характерні для дівчат-підлітків з залежною структурою особистості. Відповідно, можна відзначити наявність у хворих дівчат ознак міжособистісної залежності.

Старшу вікову групу, які страждають ВОМ, відрізняє наявність малюнків, де дитяча фігура зображується в нижній частині листа (що не помічено в КГ); в 14,3\% випадках члени сім'ї розосереджені в різних «зонах» (що зустрічається значимо частіше, ніж в КГ); сам малюнок в 71,4\% випадків займає центральну частину листа. Таким чином, дівчата реально оцінюють свої диспозиції в родині - вони «знають своє місце» і свої функції. Оскільки не задовольняються психологічні потреби дівчат, проглядається спроба з їхнього боку продемонструвати свій стан, «виявитися у центрі уваги». А розосередження кожного члена сім'ї по своїх місцях, як зазначалося вище, може ставати своєрідним захистом від недиференційованого сімейного простору.

3 малюнків дівчат з ВОМ можна бачити відсутність близьких відносин з братами/сестрами. Так, у 25\% дівчат молодшої групи вони вимальовуються останніми і є одними з найменших фігур малюнка (50\%). У старшій віковій групі відсутнє близьке розташування дитячої фігури до сиблінга, а в 14,3\% випадків сиблінга не малюють взагалі. У КГ, навпаки, спостерігаються тісні відносини 3 сиблінгами, що може розцінюватися як наявність внутрішньопоколіннихзв'язків, горизонтальних коаліцій, що забезпечують правильну структуру сім'ї [1, с. 15].

Для страждаючих ВОМ характерні вертикальні, дисфункціональні коаліції - 3 мамою (іноді 3 бабусею). Так, відзначається найбільш близьке розташування дитячої фігури до матері у 75\% дівчат в молодшій віковій групі (до бабусі у 25\%) і у 35,7\% (до бабусі у 7,1\%) - в старшій, що значимо відрізняє їх від КГ. У молодшій групі в 100\% випадках мати представлена як найбільша, значуща 
фігура. Таким чином, в сім'ях, які страждають ВОМ, спостерігається домінування матері, що призводить до порушення розвитку не тільки всієї сімейної системи, а й розвитку дитини. Це, в свою чергу, може ставати причиною статеворольової інверсії у дівчат-підлітків. Крім того, якщо образ бабусі у дівчат завжди позитивний, то образ матері носить амбівалентний характер. Так, молодші дівчата частіше в порівнянні з КГ, малюють іï останньої (50\%), обидві вікові групи відчувають труднощі при малюванні материнської фігури (відповідно в 50\% і 28,6\% випадках). Сильна мати «пригнічує» дівчину та іiі жіноче начало: дівчата молодшої групи частіше в порівнянні з КГ (25\%) малюють дитячу фігуру першою, як би намагаючись звернути увагу на свої нереалізовані потреби; в $50 \%$ випадків обидві вікові групи прорисовують ії найменьшою; у 25\% молодших і $50 \%$ старших дівчат - дитяча фігура не відповідає статі. Необхідно відзначити той факт, що у хворих на ВОМ найвищий відсоток неповних сімей - 67\%, в яких не проживає батько. Цілком припустимо, що при домінантній позиції матері у дівчат має місце ефект відкидання батька [9, с. 61], що погіршує становище дівчини у родині.

Слід також зазначити, що в малюнках дівчат з ВОМ відсутні додаткові фігури як, наприклад, двоюрідні брати/сестри, інші родичі, домашні вихованці, що значимо відрізняє їх від КГ. Це, швидше за все, є наслідком того, що дівчата відчувають свою незначність у сімейній системі, відсутність особистого простору, обмеження їх інтересів. Вони не знаходять в сім'ї місця навіть для себе. Додаткові фігури можуть бути також своєрідним захисним механізмом, здатним компенсувати дефіцит емоційно-теплих стосунків у сім'ї. У хворих на ВОМ такі механізми відсутні. Підтвердженням цього стає «неякісність», а, отже, недостатня цінність малюнка сім'ї (в 25\% випадків - у молодшій групі, і в 50\% - у старшій).

\section{Висновки.}

1. У дівчаток-підлітків, які страждають ВОМ, існують певні структурні зміни в сімейній системі, а саме:

а) недиференційованість особистісних меж кожного члена сім'ї, узагальненість сімейного простору;

б) порушення особистого простору дитини або його ізоляція;

в) незбалансованість сімейної структури, що стабілізується на основі дисфункції одного з членів сім'ї - дитини, яка втрачає можливість задовольняти власні психічні потреби;

г) наявність ознак міжособистісної залежності в результаті патогенного функціонування сімейної системи;

д) для сімей дівчат, які страждають ВОМ характерні вертикальні дисфункціональні коаліції з матір'ю, а також слабкість захисних механізмів, покликаних компенсувати дефіцит емоційно-теплих стосунків у родині;

е) інверсія домінування - внаслідок домінантної матері відбувається порушення звичної для нашої культури структури сім'ї, що в свою чергу стає джерелом статеворольової інверсії у дівчат;

2. Зближення з одним із батьків (в даному випадку з матір'ю) на шкоду відносинам з іншим батьком стає проблемним з точки зору статеворольового та, як наслідок, психосексуального розвитку.

3. Аналіз отриманих даних дозволяє припускати наявність у хворих дівчат патогенетичної i/aбо предиспонуючої ролі фактора сім'ї у виникненні таких порушень менструальної функції як ВОМ.

\section{СПИСОК ЛІТЕРАТУРИ}

1. Varga A.Y. Системная семейная психотерапия: краткий лекционный курс [Systemic family psychotherapy: a short lecture course]. - SPb.: Rech, 2001. - 144 p. (in Russian)

2. Isaev D.M. Психосоматические расстройства у детей: руководство для врачей [Psychosomatic disorders in children: a guide for doctors] / D.M. Isaev. - SPb.: Izdatelstvo «Piter», 2000. - 512 p. (in Russian)

3. Kocharyan A.S. Личность и половая роль [Personality and Sexual Role]. - Harkov: «Osnova», 1996. - 127 p. (in Russian) 
4. Levenets S.A., Dyinnik V.A., Nachetova T.A. Нарушение менструальной функции у девочек-подростков: монография [Menstrual dysfunction in adolescent girls: monograph]. - Harkiv: Natsionalnaya akademiya meditsinskih nauk Ukrainy GU «Institut ohrany zdorovya detey i podrostkov Natsionalnoy akademii meditsinskih nauk Ukrainy, 2012. - 219 p. (in Russian)

5. Malkina-Pyih I.G. Семейная терапия: Справочник практического психолога [Family Therapy: A Handbook of Practical Psychology]/I.G. Malkina-Pyih. - M.: Eksmo, 2005. - 992 p. (in Russian)

6. Nagorna A.M., Bespalko V.V. Репродуктивне здоров'я та статеве виховання молоді [Reproductive health and sexual upbringing of young people: a monograph]. - Kyiv: Vyd-vo Evrop. un-tu, 2004. - 407 p. (in Ukrainian)

7. Radzinskiy V.E. Девушки-подростки: современные тенденции формирования репродуктивного потенциала [Teenage girls: current trends in the formation of reproductive potential] / V.E. Radzinskiy, M.B. Hamoshina. Sibirskiy meditsinskiy zhurnal, 2010. - Vol. 25. - № 4. - Vypusk 2. - P. 43 - 51. (in Russian)

8. Frolova E.V. Психологічні чинники і динаміка формування стосунків міжособистісної залежності у жінок. Автореферат дисертації канд. психол. наук [Psychological factors and dynamics of formation of relations of interpersonal dependence in women: author's abstract. dis ... Cand. psychologist sciences]. - Harkiv: Harkivskiy natsionalniy universitet imeni V. N. Karazina, 2008. - 22 p. (in Ukrainian)

9. Holmogorova А.В. Роль отца в психическом развитии ребенка [The role of the father in the mental development of the child] / A.B. Holmogorova, O.G. Kalina. - M.: Forum, 2018. - 112 p. (in Russian) 